Article

\title{
Effects of Hydroxytyrosol against Lipopolysaccharide-Induced Inflammation and Oxidative Stress in Bovine Mammary Epithelial Cells: A Natural Therapeutic Tool for Bovine Mastitis
}

\author{
Roberta Fusco ${ }^{1,+} \oplus^{\circ}$, Marika Cordaro ${ }^{1,+}\left(\mathbb{D}\right.$, Rosalba Siracusa ${ }^{1}\left(\mathbb{D}\right.$, Alessio Filippo Peritore ${ }^{1}{ }^{(}$, \\ Ramona D'Amico ${ }^{1}$ (D), Patrizia Licata ${ }^{2, *}$, Rosalia Crupi ${ }^{2, *(D)}$ and Enrico Gugliandolo ${ }^{1}$ (D) \\ 1 Department of Chemical, Biological, Pharmaceutical and Environmental Science, University of Messina, \\ 98166 Messina, Italy; rfusco@unime.it (R.F.); cordarom@unime.it (M.C.); rsiracusa@unime.it (R.S.); \\ aperitore@unime.it (A.F.P.); rdamico@unime.it (R.D.); egugliandolo@unime.it (E.G.) \\ 2 Department of Veterinary Science, University of Messina, 98168 Messina, Italy \\ * Correspondence: plicata@unime.it (P.L.); rcrupi@unime.it (R.C.) \\ $\dagger$ These authors contributed equally.
}

Received: 1 July 2020; Accepted: 27 July 2020; Published: 3 August 2020

\begin{abstract}
Background: Bovine mastitis is a growing health problem, affecting both welfare of dairy cattle and milk production. It often leads to chronic infections, disturbing the quality of milk and resulting in cow death. Thus, it has a great economic impact for breeders. Methods: In this study, we evaluated the protective effect of hydroxytyrosol-a natural molecule which is the major constituent of many phyto-complexes-in an in vitro model of mastitis induced by LPS $(1 \mu \mathrm{g} / \mathrm{mL})$. Results: Our results showed that hydroxytyrosol $(10$ and $25 \mu \mathrm{M})$ was able to prevent the oxidative stress induced by LPS (intracellular ROS, GSH and NOX-1) and the consequently inflammatory response (TNF- $\alpha$, IL-1 $\beta$ and IL-6). The protective effect of hydroxytyrosol is also related to the enhancement of endogenous antioxidant systems (Nrf2, HO-1, NQO-1 and Txnrd1). Moreover, hydroxytyrosol showed an important protective effect on cell functionality ( $\alpha$-casein S1, $\alpha$-casein S2 and $\beta$-casein). Conclusions: Taken together, our results showed a significant protective effect of hydroxytyrosol on oxidative stress and inflammatory response in MAC-T cells. Thus, we indicated a possible important therapeutic role for hydroxytyrosol in the prevention or management of bovine mastitis.
\end{abstract}

Keywords: hydroxytyrosol; oxidative stress; inflammation; bovine mastitis

\section{Introduction}

Bovine Mastitis is characterized by the inflammation of the mammary gland that occurs in response to several different stimuli, such as microorganism infection [1]. The udders of infected cows are one of the major reservoir of contagious pathogens. During milking they spread from cow to cow, inducing chronic subclinical infections. Contagious pathogens include: Streptococcus agalactiae, Staphylococcus aureus, Corynebacterium bovis and Mycoplasma spp. [2]. Differently, environmental mastitis is defined as intramammary infections caused by pathogens of the environment in which the cow lives [3]. Environmental pathogens include Klebsiella spp., Escherichia coli, Streptococcus uberis and Streptococcus dysgalactiae. Most those infections are characterized by a short duration [4].

Moreover, mastitis influences yield, composition and quality of the milk produced by the affected cow and represents a serious economic issue for the farmer [5]. In particular, it often leads to culling of chronically infected cows and occasional deaths [6]. The use of antibiotics is a consolidate 
pharmacological approach for mastitis treatment that results in several side effects [7]. New studies into pharmacological approaches for the treatment of this pathology is required for reducing the use of antibiotics that are dangerous for health of consumers and antibiotic resistance spread $[7,8]$. Nowadays, several natural molecules or derivates has been tested for the treatment of bovine mastitis [9]. Natural molecules are preferred thanks to their safer use for both the animal and its derivatives [10-12]. Interesting results have been obtained from antioxidant natural compounds such as baicalein [13], moringa extract [14] and curcumin [15].

There is a well consolidated crosstalk between inflammation and oxidative stress. Recent evidences have shown the beneficial effects of the antioxidant therapy in several pathologies [8,16-22]. A key role for oxidative stress in bovine mastitis is widely recognized: dietary supplementation with antioxidant nutrients has shown protective action and improvement of immune resistance against infections [23,24]. Oxidative stress in early lactation cows plays a central role in dysfunctional inflammatory response [25]. Additionally, during the periparturient period there is an increase in the production of the reactive oxygen species. The free radicals produced induce a positive feedback which can further aggravate the pathologic condition [26]. Hydroxytyrosol (3,4-dihydroxyphenylethanol, HT) is a polyphenol mainly present in the fruit and in the leaf of Olea europaea L., a plant belonging to the Oleaceae family. This plant family comprises numerous different species distributed throughout the Mediterranean basin. HT is also the main component of extra virgin olive oil: it is present in esterified or free form and it represents the $70-80 \%$ of the total phenolic fractions [27]. High HT contents have been found in the olive leaf extract and in olive mill waste water, making it a potentially useful waste product [28]. Several works describe the antioxidant properties of HT [29]: its antioxidant power is two times higher than coenzyme Q10 and ten times higher than green tea [30]. Additionally, numerous biologic activities have been ascribed to HT, although in some cases its mechanism of action has not been clarified. Of particular interest are the anti-inflammatory and antimicrobial properties of HT, which have been described in many diseases [28,31-36]. In particular, it has been reported that HT was able to inactivate the staphylococcal enterotoxin A, a key factor in the patho-physiology of animal mastitis [37]. Therefore, the application of HT in the treatment or prevention of bovine mastitis would be an interesting therapeutic strategy.

Bovine mammary epithelial cell lines, like mammary alveolar (MAC-T) cells, are one of the most used cell lines to study inflammation, lipid metabolism and apoptosis [38-41]. In particular, MAC-T cells represent a convenient validation system for investigating lactation and bioactive substances with the mammary tissue-specific casein promoter [42]. For this process to happen, the mammary gland grows and differentiates through extensive tissue remodeling. When treated with prolactin, insulin and retinoic acid this cell line differentiates into $\beta$-casein-secreting cells [43]. In this study, we investigated the effect of HT on lipopolysaccharide-induced inflammation and oxidative stress in bovine mammary epithelial (MAC-T) cells.

\section{Materials and Methods}

\subsection{Cell Culture}

Bovine mammary epithelial cell line (MAC-T cells) [44], were cultured in DMEM medium containing 10\% fetal bovine serum (FBS) and $200 \mathrm{U} / \mathrm{mL}$ streptomycin/penicillin (Sigma-Aldrich, Milano, Italy) and incubated at $37{ }^{\circ} \mathrm{C}$ in a humidified atmosphere containing $5 \% \mathrm{CO}_{2}$. The medium was changed every $48 \mathrm{~h}$. The cells were split at $80-90 \%$ confluency using $0.25 \%$ trypsin solution.

\subsection{Cell Differentiation}

MAC-T cell were detached with $0.25 \%$ of trypsin-ethyl-enediaminetetraacetic acid (Sigma-Aldrich, Milano, Italy). The initial number of cells in each group was $5 \times 10^{4}$ cells/well in a 6-well plate and cultured for 4 days, and then the cells in each group were split on additional 6-well plates on 4 and 5 days. MAC-T cells were differentiated as already described $[45,46]$. Briefly, cells were cultured 
$(5 \times 104$ cells/well in 6-well plate) in serum-free DMEM for $16 \mathrm{~h}$ and then cultured in high-glucose DMEM addition of $5 \%$ FBS, $5-\mu \mathrm{g} / \mathrm{mL}$ insulin (Sigma, USA), 1- $\mu \mathrm{g} / \mathrm{mL}$ hydrocortisone (Sigma, USA), $5-\mu \mathrm{g} / \mathrm{mL}$ prolactin (PRL) (Sigma, USA) and 1- $\mu$ M retinoic acid (RA) (Sigma, USA). During this period, the medium was changed every $24 \mathrm{~h}$. To determine casein mRNA expression, $10-\mu \mathrm{M}$ and $25-\mu \mathrm{M}$ HT was added to cells $1 \mathrm{~h}$ before LPS-stimulation.

\subsection{Cell Treatment}

Cell were pretreated with HT (10 $\mu \mathrm{M}$ and $25 \mu \mathrm{M})$ (Sigma-Aldrich, Milano, Italy). One hour after HT pretreatment, cells were stimulated with LPS $1 \mu \mathrm{g} / \mathrm{mL}$ (Escherichia coli O111:B4, Sigma-Aldrich, Milano, Italy) for 1 or $6 \mathrm{~h}$ as previously described [47]. LPS concentrations were chosen based on previous studies by others using mammary epithelial cells $[48,49]$.

\subsection{Cell Viability Assay}

The possible toxic effect of HT on MAC-T cells was determined by methyl thiazolyl tetrazolium (MTT) assay as previously described [50]. Briefly, cells seeded in a 96-well plate and incubated with $\mathrm{HT}$ at $10,25,50,100,250 \mu \mathrm{M}$, for $24 \mathrm{~h}$ in a 96-well plate, followed by the MTT treatment $(10 \mu \mathrm{L}$ of $0.5 \mathrm{mg} / \mathrm{mL}$ ) for $4 \mathrm{~h}$. Acidic isopropanol was added to dissolve any deposited formazan. The optical density at $550 \mathrm{~nm}$ was measured using a microplate reader and used to calculate the cell viability.

\subsection{Western Blot Analysis}

Cells were lysed with a hypotonic buffer solution containing $20 \mathrm{mM}$ Tris (pH 7.4), $10 \mathrm{mM} \mathrm{NaCl}$, $3 \mathrm{mM} \mathrm{MgCl} 2$ and a protease inhibitor mixture. After addition of $10 \%$ Triton-X 100, cell lysates were centrifuged at $650 \times \mathrm{g}$ for $10 \mathrm{~min}$ at $4{ }^{\circ} \mathrm{C}$ and supernatants were collected as cytosolic fractions. Remaining pellets were resuspended in cell extraction buffer [100 mM Tris (pH 7.4), $1 \%$ Triton X-100, $10 \%$ glycerol and $0.1 \%$ SDS] containing protease inhibitor mixture. Homogenates were then centrifuged at $14,000 \times g$ for $20 \mathrm{~min}$ at $4{ }^{\circ} \mathrm{C}$ and supernatants were collected as nuclear fractions. The levels of nuclear factor erythroid 2-related factor 2 (Nrf2) quantified in nuclear fraction. The filters were blocked with $1 \times$ PBS, $5 \%(w / v)$ nonfat dried milk (PM) for $40 \mathrm{~min}$ at room temperature and subsequently probed with specific Nrf2 antibody (Novus biologicals, Centennial, CO, USA) in $1 \times \mathrm{PBS}, 5 \%$ w/v nonfat dried milk, $0.1 \%$ Tween-20 (PMT) at $4{ }^{\circ} \mathrm{C}$, overnight. Membranes were incubated with peroxidase-conjugated goat anti-rabbit IgG (1:2000, Jackson Immuno Research, West Grove, PA, USA) at room temperature for $1 \mathrm{~h}$. Laminin protein were used as internal standard for nuclear extracts. Signals were detected with enhanced chemiluminescence detection system reagent according to manufacturer's instructions (Super-Signal West Pico Chemiluminescent Substrate, Pierce). The relative expression of the protein bands was quantified by densitometry with Bio-Rad (Bio-Rad, Milan, Italy) ChemiDoc XRS software and standardized to lamin levels. A preparation of commercially, molecular weight markers made of proteins of molecular weight 10-250 kDa was used to define molecular weight positions and as reference concentrations for each molecular weight.

\subsection{Oxidative Stress Markers}

In order to evaluate total cellular reactive oxygen species (ROS) we employed the $2^{\prime}, 7^{\prime}$-dichlorodihydrofluorescein diacetate (H2DCFDA) dye. MAC-T cells were grown to confluence in 6-well plates, trypsinized and then washed twice with $1 \mathrm{x}$-washing buffer. Subsequently, cells were incubated with $1-\mu \mathrm{M}$ H2DCFDA dye at $37^{\circ} \mathrm{C}$. The fluorescence microplate reader detected the light emission. The levels of increased ROS production were expressed as percentage of the control (nmol/mL). Reduced GSH was measured by a commercially available kit (EIAGSHC, Thermo Fisher Scientific, Milan, Italy). 


\subsection{ELISA}

Secretion of TNF- $\alpha$, IL- 6 and IL- $1 \beta$ were measured using commercial ELISA kits from R\&D Systems, Minneapolis, MN, USA. Briefly, after the already described treatment, $100 \mu \mathrm{L}$ of samples or standards were added in each well and incubated for $2 \mathrm{~h}$ at room temperature. After 2 washes, $100 \mu \mathrm{L}$ of the diluted detection antibody was added to each well and incubated for $2 \mathrm{~h}$ at room temperature. After 2 washes, $100 \mu \mathrm{L}$ of the working dilution of streptavidin-HRP A was added to each well and incubated for $2 \mathrm{~h}$ at room temperature. After washes, $100 \mu \mathrm{L}$ of substrate solution was added to each well and incubated for $20 \mathrm{~min}$ at room temperature in the dark. The reaction was then stopped by adding $50 \mu \mathrm{L}$ of stop solution. Absorbance at $450 \mathrm{~nm}$ was recorded to calculate protein concentration.

\subsection{Real-Time PCR}

To evaluate the mRNA expression of target genes, RNA was extracted from MAC-T cells using RNeasy kit (Qiagen, Milan, Italy), for real-time polymerase chain reaction (PCR) analysis. Briefly, samples were first lysed and then ethanol was added to provide ideal binding conditions. The lysates were then loaded into the RNeasy silica membrane. RNA binds and all contaminants were efficiently washed away. The residual amounts of DNA remaining were removed using a convenient on-column DNase treatment. Pure, concentrated RNA was eluted in $50 \mu \mathrm{L}$ water. iScript RT-PCR kit (Bio-Rad) was used to synthesize first-strand cDNA. Briefly, the reverse transcription master mix was prepared adding to $1 \mu \mathrm{g}$ of RNA template the iScript RT Supermix (5x RT supermix with RNase H+ Moloney (gray cap, 25 or 100 reactions) murine leukemia virus (MMLV) reverse transcriptase, RNase inhibitor, dNTPs, oligo(dT), random primers, buffer, $\mathrm{MgCl} 2$ and stabilizers) and the nuclease-free water. The complete reaction mix was incubated in a thermal cycler (Priming $5 \mathrm{~min}$ at $25^{\circ} \mathrm{C}$, Reverse transcription $20 \mathrm{~min}$ at $46^{\circ} \mathrm{C}$, RT inactivation for one minute at $95^{\circ} \mathrm{C}$ ). Real-time PCR analysis was performed by SYBR Green method on a StepOnePlus real-time PCR system (Applied Biosystems, Waltham, MA, USA). PCR conditions were as follows: initial denaturation at $95^{\circ} \mathrm{C}$ for $15 \mathrm{~min}$, followed by 45 cycles of amplification at $95^{\circ} \mathrm{C}$ for $20 \mathrm{~s}$ and $60^{\circ} \mathrm{C}$ for $40 \mathrm{~s}$. Final extension at $60^{\circ} \mathrm{C}$ for $60 \mathrm{~s}$ and a hold at $4{ }^{\circ} \mathrm{C}$ were then performed. Data analysis was performed using the $2-\Delta \Delta \mathrm{Ct}$ method, in which relative mRNA expression of target mRNAs [NADPH oxidase-1 (NOX-1), heme oxygenase-1 (HO-1), NAD(P)H: quinone oxidoreductase-1 (NQO-1) and thioredoxin reductase 1 (Txnrd1) and casein isoforms] was compared to that of a constitutively expressed gene (i.e., GAPDH). Primer sequences used in this study were: NADPH oxidase-1 (NOX-1): (Bio-Rad, Italy), HO-1: (forward) AGG ATT TGT CAG AGG CCC TGA A (reverse) CAA AGA CGC CAT CAC CAG CTT A, NQO-1: (forward) GGT GCT CAT AGG GGA GTT CG (reverse) GGG AGT GTG CCC AAT GCT AT, Txnrd1: (forward) CGG TAT TGC TGG CAA TAG GAA GAG (reverse) GGC ATA GAT GTA AGG CAC GTT GGT, $\alpha$-casein S1: (forward) GGG AAT CCAT GCC CAA CAG AAA GA (reverse) GGA ACG TAA TAC CAG GCA CCA GAT, $\alpha$-casein S2: (forward) GGA CGA TAA GCA CTA CCA GAA AGC (reverse) AGA GTG GGA GTA ATG GGA ACA GCA, $\beta$ casein: (forward) CCT AAC AGC CTC CCA CAA AA (reverse) AGA CTG GAG CAG AGG CAG AG, GAPDH (forward) ATG ATT CCA CCC ACG GCA AGT T (reverse) ACC ACA TAC TCA GCA CCA GCA T. The results are expressed as fold-changes [51].

\subsection{Statistical Analysis}

For each experiment, three or more independent experiments were performed and for each experiment five repeat samples were used. The data resulting from all experiments are expressed as means \pm SEM. Statistical differences between groups were compared using ANOVA, followed by Tukey's test. A $p$-value of less than 0.05 was considered statistically significant. 


\section{Results}

\subsection{HT Effect on MAC-T Cell Viability}

First, we investigated any toxic effect of HT on the MAC-T cells by the MTT cell viability assay. The concentrations of HT evaluated were 10, 25, 50, 100 and $250 \mu \mathrm{M}$. Cells were incubated with HT for $24 \mathrm{~h}$ and then treated with MTT $(10 \mu \mathrm{L}$ of $0.5 \mathrm{mg} / \mathrm{mL})$ for $4 \mathrm{~h}$. As show in Figure 1, no statistical differences were detected at $10-, 25-$ and $50-\mu \mathrm{M}$ HT (respectively $99.2 \% \pm 0.37 ; 99 \% \pm 0.44$; $96.8 \% \pm 1.77)$ than the control. We found a significant reduction in cell viability at the concentration of $100(94.6 \% \pm 1.2)$ and $250 \mu \mathrm{M}(93.3 \% \pm 1.56)$ (Figure 1B and Table S1 in Supplemental Material).

A

Hydroxytyrosol (HT)<smiles>OCCc1ccc(O)c(O)c1</smiles>

B

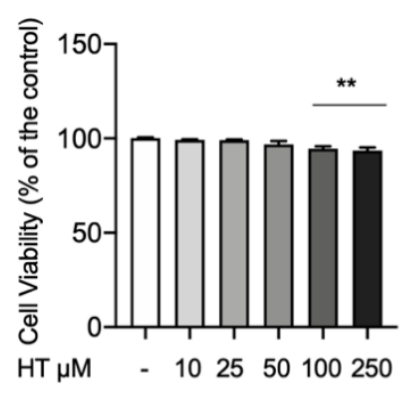

Figure 1. (A) Chemical structure of hydroxytyrosol and (B) effect on cell viability MTT assay. Data representative of at least three experiments, means $\pm \mathrm{SEM}$; ${ }^{* *} p<0.01$ vs. control.

\subsection{Protective Effect of HT in LPS Induced Oxidative Stress in MAC-T Cell}

To test whether the protective effect of HT in LPS induced oxidative stress, we pretreated the MAC-T cell with HT (10- $\mu \mathrm{M}$ and $25 \mu \mathrm{M})$ for $1 \mathrm{~h}$ and then stimulated them with LPS $1-\mu \mathrm{g} / \mathrm{mL}$ for $1 \mathrm{~h}$ and $6 \mathrm{~h}$. One hours after LPS-stimulation increased oxidative stress was detected, as shown by the increased levels of intracellular ROS (Figure 2A), reduction in GSH levels (Figure 2B), than control (282 \pm 8.6 vs. $100 \pm 0.37$ for ROS and $0.5 \pm 0.05$ vs. $0.95 \pm 0.02$ for GSH, respectively). This trend was confirmed by the upregulation of the NADPH oxidase- 1 (NOX-1) mRNA level (Figure 2C), than control (2.76 \pm 0.11 ). HT treatment $(10 \mu \mathrm{M}$ and $25 \mu \mathrm{M})$ reduced in a dose dependent manner the cellular oxidative stress by reducing NOX-1 mRNA expression (HT $10 \mu \mathrm{M}: 2.28 \pm 0.08$ ) (HT $25 \mu \mathrm{M}: 1.98 \pm 0.12$ ) (Figure 2C) and ROS intracellular levels (HT $10 \mu \mathrm{M}$ : 227.4 \pm 19.02 and HT $25 \mu \mathrm{M}$ : 211. \pm 8.87) (Figure 2A) and increasing GSH levels (HT $10 \mu \mathrm{M}: 0.7 \pm 0.04$ and HT $25 \mu \mathrm{M}: 0.78 \pm 0.05$ ) (Figure 2B) (Table S2 in Supplemental Material). Additionally, we evaluated the same parameters six hours after LPS-stimulation. LPS increased ROS and GSH levels than control ( $321 \pm 14.18$ vs. $100 \pm 0$ for ROS and $0.4 \pm 0.05$ vs. $0.96 \pm 0.02$ for GDH, respectively) (Figure 2D,E, respectively). HT treatment was able to reduce intracellular ROS levels (HT $10 \mu \mathrm{M}: 245 \pm 14.49$ and HT $25 \mu \mathrm{M}: 200.2 \pm 6$ ) and increase GSH levels (HT $10 \mu \mathrm{M}: 0.74 \pm 0.06$ and HT $25 \mu \mathrm{M}$ : $0.84 \pm 0.06)$. RT-PCR analysis for NOX-1 mRNA expression showed increased levels in LPS treated cells than control (2.74 \pm 0.10$)$ (Figure $2 \mathrm{~F}$ ). HT treatment at $10 \mu \mathrm{M}$ and $25 \mu \mathrm{M}$ reduced NOX-1 mRNA expression (HT $10 \mu \mathrm{M}: 2.18 \pm 0.08$ and HT $25 \mu \mathrm{M}: 1.78 \pm 0.10$ ) (Figure 2F and Table S3 in Supplemental Material). 
A

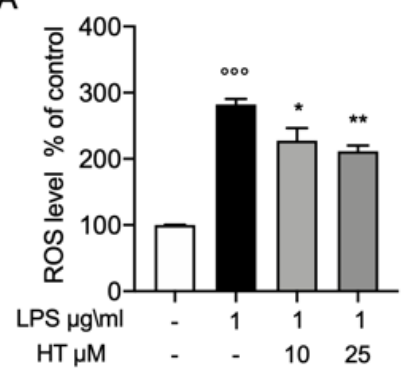

D

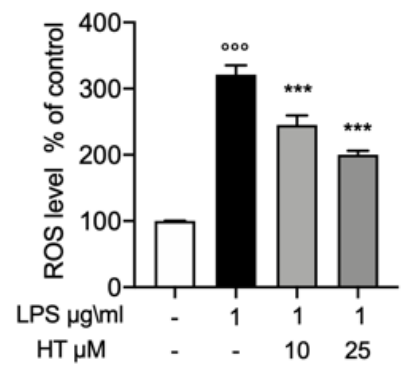

$1 \mathrm{~h}$

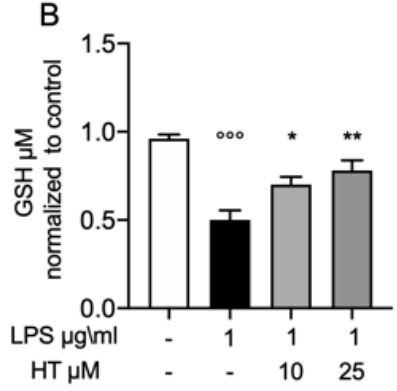

$6 \mathrm{~h}$

$\mathrm{E}$

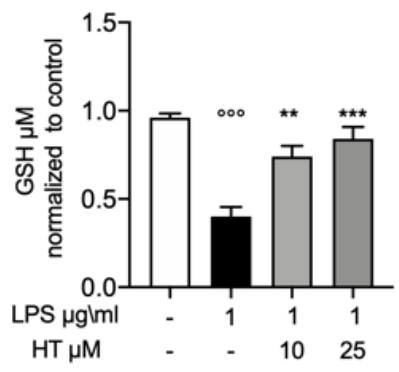

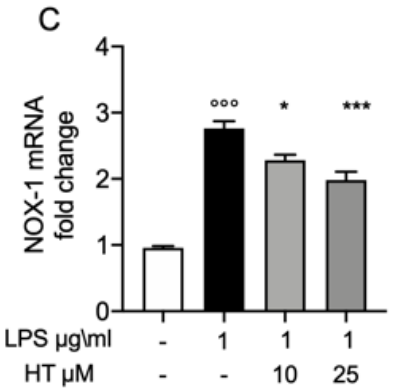

$\begin{array}{lllrr}\mathrm{HT} \mu \mathrm{M} & - & - & 10 & 25\end{array}$

$\mathrm{F}$

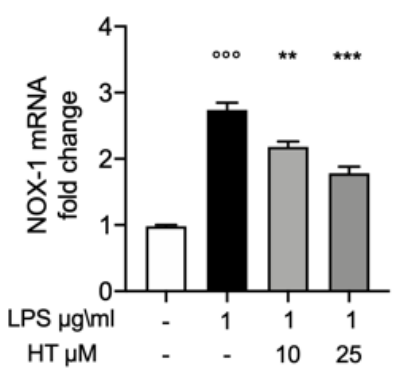

Figure 2. Protective effect of hydroxytyrosol (HT) in LPS $(1 \mu \mathrm{g} / \mathrm{mL})$ induced oxidative stress in MAC-T cell. (A) Intracellular ROS, (B) GSH levels and (C) NOX-1 mRNA levels, one hour post stimulation LPS; (D) intracellular ROS, (E) GSH levels and (F) NOX-1 mRNA levels, six hours post LPS. Data representative of at least three experiments, means $\pm \mathrm{SEM} ;{ }^{\circ 00} p<0.001 \mathrm{vs.}$ control; ${ }^{*} p<0.05 \mathrm{vs}$. LPS; ${ }^{* *} p<0.01$ vs. LPS; ${ }^{* * *} p<0.001$ vs. LPS.

\subsection{Protective Effect of HT in LPS Induced Inflammatory Response in MAC-T Cell}

Increased in oxidative stress is closely related with the inflammatory response. One hour after LPS-stimulation $(1 \mu \mathrm{g} / \mathrm{mL})$ we found a significant increased levels of the main inflammatory cytokines TNF- $\alpha(3060 \pm 163.1$ vs. $450 \pm 97.47)$, IL-1 $\beta(2214 \pm 154.9$ vs. $118 \pm 34.26)$ and IL-6 (3840 \pm 120.8 vs. $170 \pm 30$ ) (Figure $3 \mathrm{~A}$ ). The treatment with $\mathrm{HT}$ at the concentration of 10 and $25 \mu \mathrm{M}$ significant prevent the increase of TNF- $\alpha$ (HT $10 \mu \mathrm{M}: 2160 \pm 271.3$ and HT $25 \mu \mathrm{M}: 1880 \pm 276.4$ ), IL-1 $\beta$ (HT $10 \mu \mathrm{M}$ : $1650 \pm 120.4$ and HT $25 \mu \mathrm{M}: 1400 \pm 138.7$ ) and IL-6 levels (HT $10 \mu \mathrm{M}: 2760 \pm 317.2$ and HT $25 \mu \mathrm{M}$ : $2720 \pm 171.5$ ) (Figure S3A and Table S2 in Supplemental Material). The levels of TNF- $\alpha$, IL- $1 \beta$ and IL-6 were still significantly higher than the control group, six hours after LPS-stimulation (3876 \pm 85.88 vs. $270 \pm 86.02$ for TNF- $\alpha, 2988 \pm 63.98$ vs. $118 \pm 34.26$ for IL- $1 \beta, 3074 \pm 119.6$ vs. $170 \pm 30$ for IL-6) (Figure 3B). Where compared to LPS $(1 \mu \mathrm{g} / \mathrm{mL})$ the treatment with HT at $10 \mu \mathrm{M}$ and $25 \mu \mathrm{M}$ significant

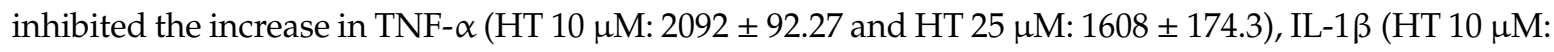
$1842 \pm 105.4$ and HT $25 \mu \mathrm{M}: 1288 \pm 151)$ and IL-6 expression (HT $10 \mu \mathrm{M}: 2179 \pm 104.9$ and HT $25 \mu \mathrm{M}$ : $1572 \pm 192.8$ ) (Figure 3B and Table S3 in Supplemental Material). 


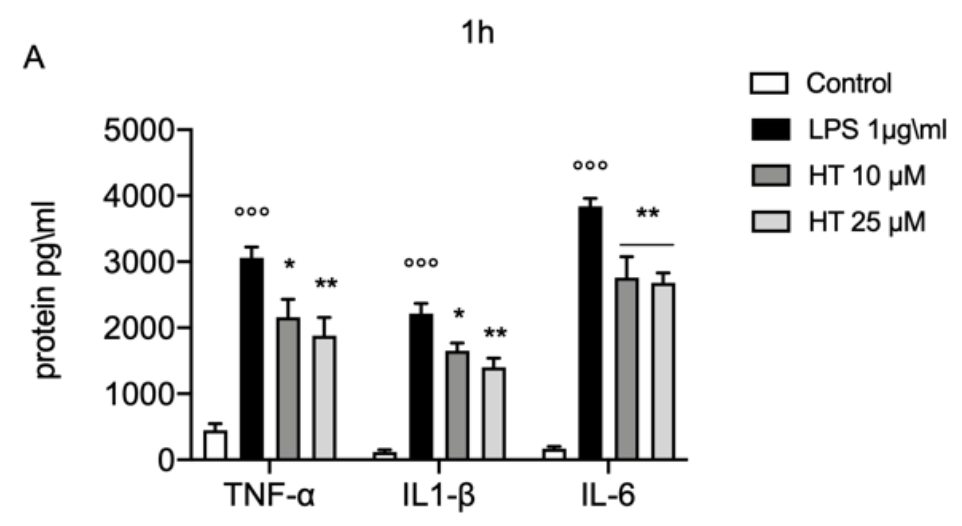

B

$6 \mathrm{~h}$

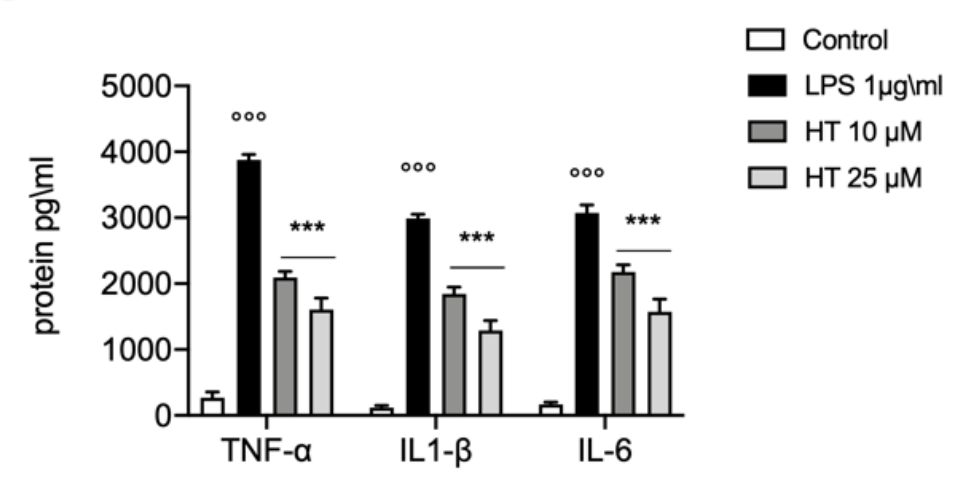

Figure 3. Protective effect of HT in LPS induced inflammatory response in MAC-T cell. (A) TNF- $\alpha$, IL- $1 \beta$ and IL-6 levels one hour after LPS-stimulation $1 \mu \mathrm{g} / \mathrm{mL}$; (B) TNF- $\alpha$, IL-1 $\beta$ and IL-6 levels six hours after LPS-stimulation $1 \mu \mathrm{g} / \mathrm{mL}$. Data representative of at least three experiments, means \pm SEM; ${ }^{\circ 00} p<0.001$ vs. control; ${ }^{*} p<0.05$ vs. LPS; ${ }^{* *} p<0.01$ vs. LPS; ${ }^{* * *} p<0.001$ vs. LPS.

\subsection{Protective Effect of HT in LPS Induced Oxidative Stress in MAC-T Cell}

The inflammation and oxidative stress induced by LPS-stimulation is closely associated with the activation of the Nrf2/Keap1 system and the antioxidant genes that it regulates. In order to evaluate the effect of the HT treatment on the activation of the Nrf2 pathway western blot analysis were conducted. Basal Nrf2 expression was detected in the control group $(1,322,619 \pm 250)$ (Figure 4A). Already after $1 \mathrm{~h}$ from LPS-stimulation Nrf2 expression were increased $(3,375,711 \pm 500)$ and HT treatment at both concentrations (10 $\mu \mathrm{M}$ and $25 \mu \mathrm{M}$ ) upregulated its expression (HT $10 \mu \mathrm{M}: 9,191,217 \pm 1000$ and HT $25 \mu \mathrm{M}: 9,849,095 \pm 500$ ) (Figure 4A). After six hours from LPS induction the Nrf2 expression was found upregulated than the control $(9,703,125 \pm 200$ vs. 2,898,569 \pm 200$)$ and HT $(10 \mu \mathrm{M}$ and $25 \mu \mathrm{M}$ ) augmented its expression (HT $10 \mu \mathrm{M}: 32,167,176 \pm 166,666$ and HT $25 \mu \mathrm{M}: 35,553,255 \pm 233,333$ ) (Figure 4B). 
$1 \mathrm{~h}$
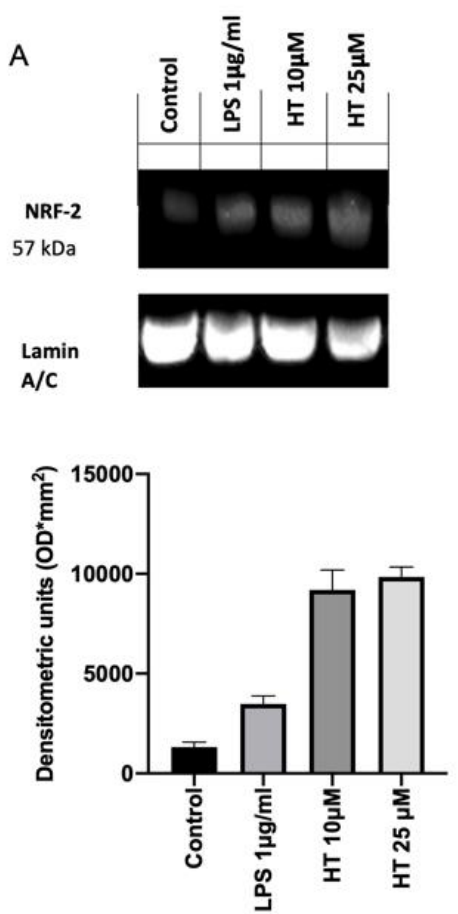

$6 \mathrm{~h}$
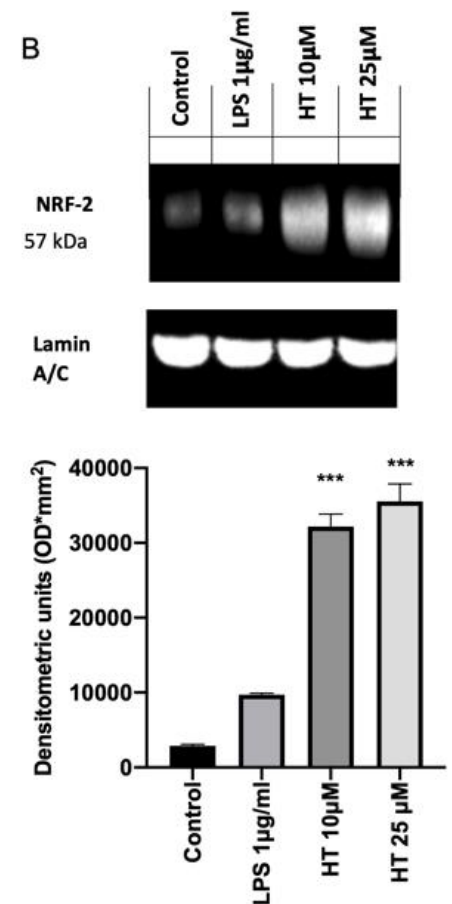

Figure 4. (A) Effect of HT on NRF2 expression: western blot analysis of NRF2 $1 \mathrm{~h}$ after LPS $1 \mu \mathrm{g} / \mathrm{mL}$ stimulation and 10- $\mu \mathrm{M}$ and $25-\mu \mathrm{M}$ HT treatment; (B) western blot analysis of NRF2 $6 \mathrm{~h}$ after LPS $1 \mu \mathrm{g} / \mathrm{mL}$ stimulation and $10-\mu \mathrm{M}$ and $25-\mu \mathrm{M}$ HT treatment. Data representative of at least three experiments, means \pm SEM; ${ }^{* * *} p<0.001$ vs. LPS.

\subsection{Antioxidant Effects of HT in LPS Induced Oxidative Stress in MAC-T Cell}

To further confirm the protective effects of HT on oxidative stress, we evaluated the expression of some of the endogenous antioxidant systems. In particular, we investigated by RT-PCR the mRNA expression of heme oxygenase-1 (HO-1), NAD(P)H quinone oxidoreductase-1 (NQO-1) and thioredoxin reductase 1 (Txnrd1). Already after $1 \mathrm{~h}$ from LPS-stimulation HO-1, NQO-1 and Txnrd1 mRNA expression were reduced $(0.82 \pm 0.05,0.78 \pm 0.06,0.61 \pm 0.04$, respectively) and HT treatment at both concentrations was able to increase them expressions (HT $10 \mu \mathrm{M}: 1.18 \pm 0.08,1.17 \pm 0.07$ and $0.99 \pm 0.09$, respectively; HT $25 \mu \mathrm{M}: 1.22 \pm 0.07,1.38 \pm 0.13$ and $1.06 \pm 0.14$, respectively) (Figure 5A and Table S2 in Supplemental Material). Six hours after LPS-stimulation, the HO-1, NQO-1 and Txnrd1 mRNA levels were significantly reduced $(0.7 \pm 0.08,0.59 \pm 0.08$ and $0.53 \pm 0.06$, respectively) (Figure $5 \mathrm{~B})$. The $10-\mu \mathrm{M}$ and $25-\mu \mathrm{M}$ HT treatment significantly improve the endogenous antioxidant capacity MAC-T cells by increasing in a dose dependent manner HO-1, NQO-1 and Txnrd1 mRNA expression (HT $10 \mu \mathrm{M}$ : $1.2 \pm 0.04,1.19 \pm 0.13$ and $1.09 \pm 0.09$; HT $25 \mu \mathrm{M}: 1.56 \pm 0.07,1.48 \pm 0.08$ and $1.2 \pm 0.13$, respectively) (Figure 5B and Table S3 Supplemental Material).

\subsection{Protective Effect of HT on Casein Stimulation in LPS Stimulated MAC-T Differentiated Cell}

Synthesis of milk is one of major complication in bovine mastitis. In order to evaluate the protective effect of HT on this parameter we evaluate the mRNA expressions of casein, including $\alpha \mathrm{S} 1$, $\alpha \mathrm{S} 2$ and $\beta$ genes in MAC-T differentiated cell. The levels of $\alpha$-casein S1, $\alpha$-casein S2 and $\beta$ casein $12 \mathrm{~h}$ after LPS-stimulation were significantly reduced $(0.37 \pm 0.07,0.34 \pm 0.06$ and $0.40 \pm 0.08$, respectively) (Figure 6A-C, respectively). While HT pre-treatment $10 \mu \mathrm{M}$ and $25 \mu \mathrm{M}$ significantly antagonized this reduction in a dose dependent manner (HT $10 \mu \mathrm{M}: 0.75 \pm 0.08,0.71 \pm 0.12$ and $0.90 \pm 0.09$; HT $25 \mu \mathrm{M}$ : $1.01 \pm 0.06,1.07 \pm 0.08$ and $1.18 \pm 0.09$ ) (Figure 6A-C and Table S4 in Supplemental Material). 
A

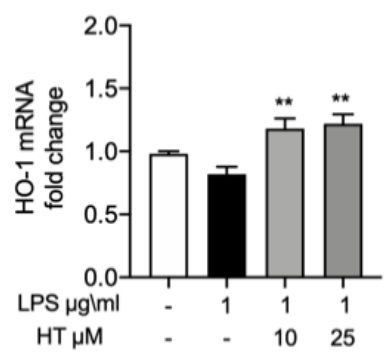

B

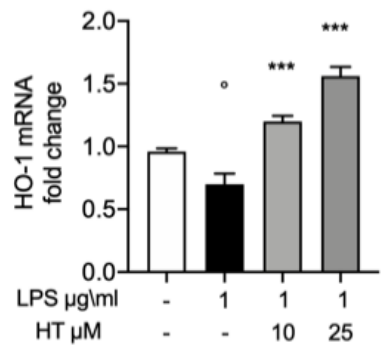

$1 \mathrm{~h}$
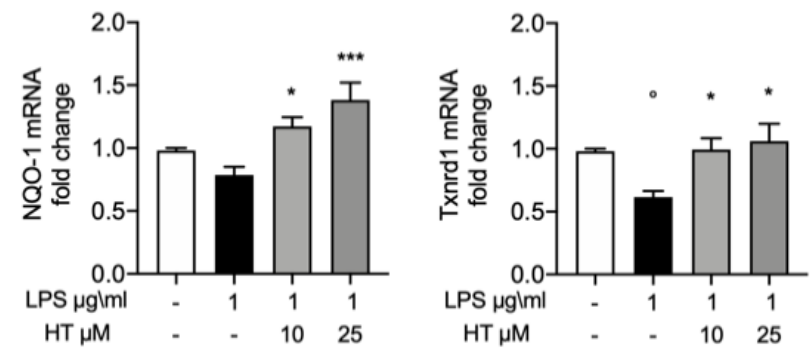

$6 \mathrm{~h}$
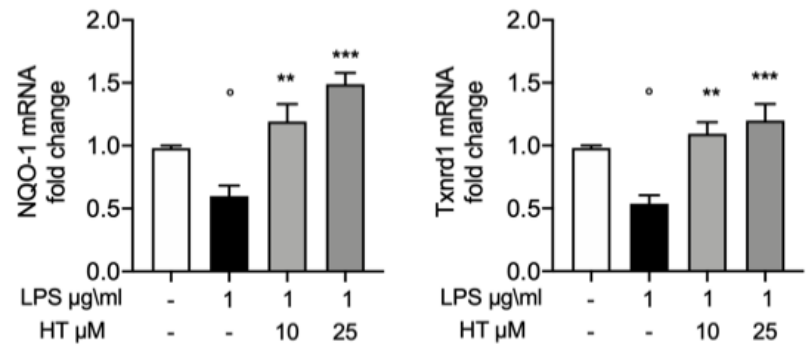

Figure 5. (A) Protective effect of HT in LPS induced oxidative stress in MAC-T cell: mRNA levels of HO-1, NQO-1 and Txnrd1 one hour post LPS $1 \mu \mathrm{g} / \mathrm{mL}$ stimulation and $10-\mu \mathrm{M}$ and $25-\mu \mathrm{M}$ HT treatment; (B) mRNA levels of HO-1, NQO-1 and Txnrd1 six hours post LPS $1-\mu \mathrm{g} / \mathrm{mL}$ stimulation and $10-\mu \mathrm{M}$ and $25-\mu \mathrm{M}$ HT treatment. Data representative of at least three experiments, means $\pm \mathrm{SEM} ;{ }^{\circ} p<0.05 \mathrm{vs}$. control; ${ }^{*} p<0.05$ vs. LPS; ${ }^{* *} p<0.01$ vs. LPS; ${ }^{* *} p<0.001$ vs. LPS.

A

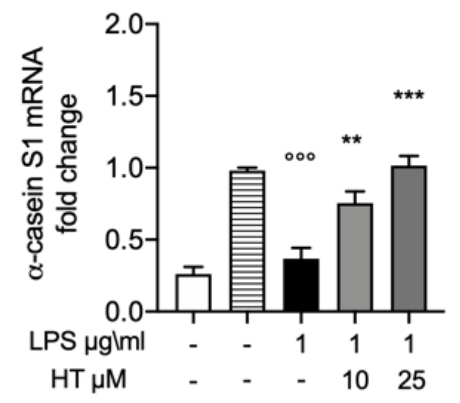

C

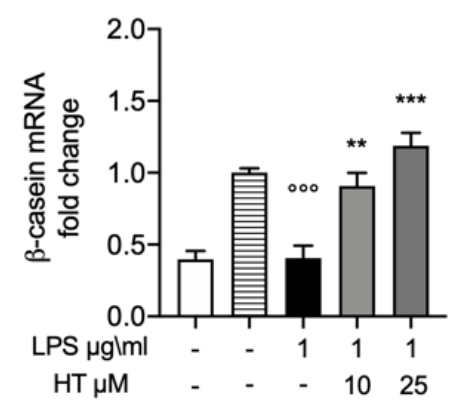

B

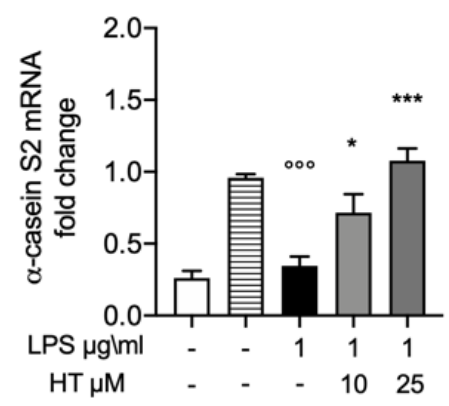

$\square$ no differentiation 目 differentiation

Figure 6. (A) Protective effect of HT on casein stimulation in LPS stimulated MAC-T differentiated cell: mRNA levels of $\alpha$-casein S1; (B) $\alpha$-casein S2 and (C) $\beta$-casein. Data representative of at least three experiments, means \pm SEM; ${ }^{\circ \circ \circ} p<0.001$ vs. control differentiated; ${ }^{*} p<0.05$ vs. LPS; ${ }^{* *} p<0.01$ vs. LPS; ${ }^{* * *} p<0.001$ vs. LPS. 


\section{Discussion}

Mastitis is widespread clinical disease in livestock and humans induced by microbial infection. The most used therapy to treat this pathology are the antibiotics, but they are related with significant side effects [52]. Investigating new therapeutic tools with fewer side effects is an important goal for the research. In this study, we showed for the first time the that HT, a well-known antioxidant natural compound, significantly reduced the LPS-induced inflammatory response in MAC-T cells. Additionally, we showed that HT treatment was able to increase the expression of $\alpha$-casein S1, $\alpha$-casein S2 and $\beta$ casein in MAC-T differentiated cells after LPS-stimulation.

Recently, it has been demonstrated HT attenuate oxidative stress (glutathione (GSH/GSSH), $\gamma$-glutamylcysteine ligase activity, reactive oxygen species and malondialdehyde (MDA) production) and inflammatory response (TNF- $\alpha$, IL-1 $\beta$, IL-6 and IL-10) in bovine mammary epithelial cell line (BME-UV1) [53]. First of all, we tested the any toxic effect of HT on MAC-T cells by the MTT assay, based on the metabolic activity of the cells. A significant reduction in cell viability was observed at the concentration of 100 and $250 \mu \mathrm{M}$. Recent papers also described the HT toxicity at these concentrations and ascribed it to the HT pro-apoptotic action [29,54]. Once tested the good safety of HT, we moved to investigate its effect on the oxidative stress induced by LPS-stimulation. Previous studies shown the key role of the oxidative stress in mastitis. Overproduction of free oxygen radicals is an early event in answer to bacterial infection or LPS in MAC-T cells. Our results displayed increased oxidative stress as shown by the upregulated intracellular ROS expression and the reduced GSH level. HT pretreatment at $10 \mu \mathrm{M}$ and $25 \mu \mathrm{M}$ was able to prevent the increase in oxidative stress in a dose dependent manner. Additionally, we showed that HT reduced NOX-1 mRNA expression. The upregulation of this mitochondrial protein has been linked with the ROS overproduction [55]. Thus, HT pretreatment mitigated LPS-induced NOX-1 expression and ROS generation in MAC-T cells, hinting that HT has important effect against LPS-induced oxidative stress. Several lines of evidence have described that ROS overexpression LPS-induced in turn produces cytokines release [56]. Well in line with literature our study showed increased expression of TNF- $\alpha$, IL- $1 \beta$ and IL- 6 one and six hours after LPS-stimulation. The $10-\mu \mathrm{M}$ and $25-\mu \mathrm{M}$ HT treatment significantly prevent the increase of TNF- $\alpha$, IL- $1 \beta$ and IL-6 LPS-induced. Several evidence suggest that HT is significantly able to improve endogenous antioxidant defense mechanisms by modulating transcription factors such as the Nrf2 [56,57]. Nrf2 is an important regulator of antioxidant signaling. It binds the epoxy chloropropane Kelch sample related protein-1 (Keap1) under homeostatic conditions. When the oxidative stress occurs, in cytoplasm the complex of Nrf2 and Keap1 is dissociated, and Nrf2 enters the nucleus [58]. Once translocated in the nucleus, Nrf2 binds to antioxidant response elements (ARE), promoting the transcriptional activation of metabolizing enzymes/antioxidant proteins enzymes (superoxide dismutase (SOD), Catalase (CAT), glutathione peroxidase (GSH-Px)) in phase II $[59,60]$. ROS produced by redox reactions can activate Nrf2 by promoting disulfide formation with Keap1 [61]. Therefore, the Nrf2-ARE signaling pathway is the main mechanism for defense against oxidative stress in cells by activating phase II metabolic enzymes/antioxidant protein enzymes [62].Our results showed upregulated the Nrf2 expression after one six hours from LPS-stimulation and HT treatment at bot concentrations $(10 \mu \mathrm{M}$ and $25 \mu \mathrm{M})$ increased its expression, confirming that HT antioxidant mechanism is mediated by the Nrf2 pathway. To further confirm the mechanism of the protective effect of HT we evaluated the mRNA expression of several antioxidant enzymes. In particular, our study displayed reduced heme oxygenase-1 (HO-1), $\mathrm{NAD}(\mathrm{P}) \mathrm{H}$ : quinone oxidoreductase (NQO-1), thioredoxin reductase 1 (Txnrd1) mRNA expression after LPS-stimulation. These antioxidant enzymes are phase II detoxifying proteins that provide intracellular defensive mechanism [14]. Our data displayed that the mRNA expressions of these antioxidant genes were upregulated in MAC-T cells treated with HT, suggesting that HO-1, NQO-1 and Txnrd1 are involved in the antioxidant mechanism of HT. These findings are well in line with precedent papers showing that HT reduces antioxidant enzymes [29].

One of the main functions of the bovine mammary epithelial cells is lactation. It involves prolactin, a hormone secreted by the anterior pituitary gland [63]. During lactogenesis and pregnancy prolactin 
has a crucial role in the mammary gland [64,65]. MAC-T cells stimulated by prolactin together with hydrocortisone, retinoic acid and insulin secret more $\beta$-casein $[45,46,66]$. Mammary epithelial cell differentiation is identified by the activation of genes coding for milk proteins [67]. Bovine mastitis causing cellular damage leads to disruption in lactation. We evaluated the protective effect of HT on this peculiar cell function evaluating the $\alpha$-casein S1, $\alpha$-casein S2 and $\beta$-casein mRNA levels $[68,69]$. LPS-stimulation induced the downregulation on the casein genes ( $\alpha$-casein S1, $\alpha$-casein $S 2$ and $\beta$-casein). HT increased the expression levels of three casein isoforms, indicating that protective effect of HT also preserves an important cell functionality.

\section{Conclusions}

Our results demonstrate that LPS challenge in MAC-T cell leads to an important increase in oxidative stress and inflammatory response, process that in differentiated MAC-T cells cause a significative impairment in cell functionality such as lactation. Our results showed also that the treatment with the well-known natural molecule HT, has a significantly protective effects. Together with the decrease of oxidative stress the inhibition of proinflammatory cytokines increase is a fundamental step in antagonizing the pathologic process and therefore in preventing or blocking the progression of bovine mastitis. Furthermore, HT treatment was able to significantly improve the cell antioxidant defense. Finally, this protective action of HT is traduced in an important cell functionality such as milk production. These results open a natural good prospective for the use of HT in treatment and prevention of bovine mastitis.

Supplementary Materials: The following are available online at http://www.mdpi.com/2076-3921/9/8/693/s1, Table S1: Effects of HT on cell viability MTT assay, Table S2: Effects of HT on inflammation and oxidative stress in MAC-T cells stimulated with LPS for $1 \mathrm{~h}$, Table S3: Effects of HT on inflammation and oxidative stress in MAC-T cells stimulated with LPS for $6 \mathrm{~h}$, Table S4: Effects of HT on casein isoforms in differentiated MAC-T cells.

Author Contributions: Conceptualization, EG and RC; methodology, R.F.; M.C. and R.S.; formal analysis, A.F.P. and R.D.; data curation, A.F.P. and R.D.; writing — original draft preparation, E.G.; writing-review and editing, supervision, P.L. and R.C. All authors have read and agreed to the published version of the manuscript.

Funding: This research received no external funding.

Conflicts of Interest: The authors declare no conflicts of interest.

\section{References}

1. Wang, T.; Guo, M.; Song, X.; Zhang, Z.; Jiang, H.; Wang, W.; Fu, Y.; Cao, Y.; Zhu, L.; Zhang, N. Stevioside plays an anti-inflammatory role by regulating the NF-kappaB and MAPK pathways in S. aureus-infected mouse mammary glands. Inflammation 2014, 37, 1837-1846. [CrossRef] [PubMed]

2. Radostits, O.M.; Gay, C.C.; Hinchcliff, K.W.; Constable, P.D. Veterinary Medicine E-Book: A Textbook of the Diseases of Cattle, Horses, Sheep, Pigs and Goats; Elsevier Health Sciences: Amsterdam, The Netherlands, 2006.

3. Smith, K.L.; Todhunter, D.; Schoenberger, P. Environmental mastitis: Cause, prevalence, prevention. J. Dairy Sci. 1985, 68, 1531-1553. [CrossRef]

4. Harmon, R. Physiology of mastitis and factors affecting somatic cell counts. J. Dairy Sci. 1994, 77, $2103-2112$. [CrossRef]

5. Seegers, H.; Fourichon, C.; Beaudeau, F. Production effects related to mastitis and mastitis economics in dairy cattle herds. Vet. Res. 2003, 34, 475-491. [CrossRef]

6. Abebe, R.; Hatiya, H.; Abera, M.; Megersa, B.; Asmare, K. Bovine mastitis: Prevalence, risk factors and isolation of Staphylococcus aureus in dairy herds at Hawassa milk shed, South Ethiopia. BMC Vet. Res. 2016, 12, 270. [CrossRef]

7. Gomes, F.; Henriques, M. Control of Bovine Mastitis: Old and Recent Therapeutic Approaches. Curr. Microbiol. 2016, 72, 377-382. [CrossRef]

8. Gugliandolo, E.; Fusco, R.; D’Amico, R.; Peditto, M.; Oteri, G.; Di Paola, R.; Cuzzocrea, S.; Navarra, M. Treatment With a Flavonoid-Rich Fraction of Bergamot Juice Improved Lipopolysaccharide-Induced Periodontitis in Rats. Front. Pharm. 2018, 9, 1563. [CrossRef] 
9. Caudell, M.A.; Quinlan, M.B.; Quinlan, R.J.; Call, D.R. Medical pluralism and livestock health: Ethnomedical and biomedical veterinary knowledge among East African agropastoralists. J. Ethnobiol. Ethnomed. 2017, 13, 7. [CrossRef]

10. Grzesiak, B.; Kolodziej, B.; Glowacka, A.; Krukowski, H. The Effect of Some Natural Essential Oils Against Bovine Mastitis Caused by Prototheca zopfii Isolates In Vitro. Mycopathologia 2018, 183, 541-550. [CrossRef]

11. Zhong, W.; Shen, J.; Liao, X.; Liu, X.; Zhang, J.; Zhou, C.; Jin, Y. Camellia (Camellia oleifera Abel.) seed oil promotes milk fat and protein synthesis-related gene expression in bovine mammary epithelial cells. Food Sci. Nutr. 2020, 8, 419-427. [CrossRef]

12. Wang, K.; Jin, X.L.; Shen, X.G.; Sun, L.P.; Wu, L.M.; Wei, J.Q.; Marcucci, M.C.; Hu, F.L.; Liu, J.X. Effects of Chinese Propolis in Protecting Bovine Mammary Epithelial Cells against Mastitis Pathogens-Induced Cell Damage. Mediat. Inflamm. 2016, 2016, 8028291. [CrossRef] [PubMed]

13. He, X.; Wei, Z.; Zhou, E.; Chen, L.; Kou, J.; Wang, J.; Yang, Z. Baicalein attenuates inflammatory responses by suppressing TLR4 mediated NF-kappaB and MAPK signaling pathways in LPS-induced mastitis in mice. Int. Immunopharmacol. 2015, 28, 470-476. [CrossRef] [PubMed]

14. Cheng, W.N.; Jeong, C.H.; Seo, H.G.; Han, S.G. Moringa Extract Attenuates Inflammatory Responses and Increases Gene Expression of Casein in Bovine Mammary Epithelial Cells. Animals 2019, 9, 391. [CrossRef]

15. Fu, Y.; Gao, R.; Cao, Y.; Guo, M.; Wei, Z.; Zhou, E.; Li, Y.; Yao, M.; Yang, Z.; Zhang, N. Curcumin attenuates inflammatory responses by suppressing TLR4-mediated NF-kappaB signaling pathway in lipopolysaccharide-induced mastitis in mice. Int. Immunopharmacol. 2014, 20, 54-58. [CrossRef] [PubMed]

16. Fusco, R.; Cirmi, S.; Gugliandolo, E.; Di Paola, R.; Cuzzocrea, S.; Navarra, M. A flavonoid-rich extract of orange juice reduced oxidative stress in an experimental model of inflammatory bowel disease. J. Funct. Foods 2017, 30, 168-178. [CrossRef]

17. Di Paola, R.; Fusco, R.; Gugliandolo, E.; D'Amico, R.; Campolo, M.; Latteri, S.; Carughi, A.; Mandalari, G.; Cuzzocrea, S. The Antioxidant Activity of Pistachios Reduces Cardiac Tissue Injury of Acute Ischemia/Reperfusion (I/R) in Diabetic Streptozotocin (STZ)-Induced Hyperglycaemic Rats. Front. Pharm. 2018, 9, 51. [CrossRef] [PubMed]

18. Siracusa, R.; Fusco, R.; Peritore, A.F.; Cordaro, M.; D’Amico, R.; Genovese, T.; Gugliandolo, E.; Crupi, R.; Smeriglio, A.; Mandalari, G.; et al. The Antioxidant and Anti-Inflammatory Properties of Anacardium occidentale L. Cashew Nuts in a Mouse Model of Colitis. Nutrients 2020, 12, 834. [CrossRef]

19. Fusco, R.; Siracusa, R.; Peritore, A.F.; Gugliandolo, E.; Genovese, T.; D'Amico, R.; Cordaro, M.; Crupi, R.; Mandalari, G.; Impellizzeri, D.; et al. The Role of Cashew (Anacardium occidentale L.) Nuts on an Experimental Model of Painful Degenerative Joint Disease. Antioxidants 2020, 9, 511. [CrossRef]

20. Di Paola, R.; Fusco, R.; Gugliandolo, E.; Crupi, R.; Evangelista, M.; Granese, R.; Cuzzocrea, S. Co-micronized Palmitoylethanolamide/Polydatin Treatment Causes Endometriotic Lesion Regression in a Rodent Model of Surgically Induced Endometriosis. Front. Pharm. 2016, 7, 382. [CrossRef]

21. Britti, D.; Crupi, R.; Impellizzeri, D.; Gugliandolo, E.; Fusco, R.; Schievano, C.; Morittu, V.M.; Evangelista, M.; Di Paola, R.; Cuzzocrea, S. A novel composite formulation of palmitoylethanolamide and quercetin decreases inflammation and relieves pain in inflammatory and osteoarthritic pain models. BMC Vet. Res. 2017, 13, 229. [CrossRef]

22. Cordaro, M.; Impellizzeri, D.; Siracusa, R.; Gugliandolo, E.; Fusco, R.; Inferrera, A.; Esposito, E.; Di Paola, R.; Cuzzocrea, S. Effects of a co-micronized composite containing palmitoylethanolamide and polydatin in an experimental model of benign prostatic hyperplasia. Toxicol. Appl. Pharm. 2017, 329, 231-240. [CrossRef] [PubMed]

23. Erskine, R.J. Nutrition and mastitis. Vet. Clin. N. Am. Food Anim. Pr. 1993, 9, 551-561. [CrossRef]

24. Taga, I.; Lan, C.Q.; Altosaar, I. Plant essential oils and mastitis disease: Their potential inhibitory effects on pro-inflammatory cytokine production in response to bacteria related inflammation. Nat. Prod. Commun. 2012, 7, 675-682. [CrossRef] [PubMed]

25. Mavangira, V.; Sordillo, L.M. Role of lipid mediators in the regulation of oxidative stress and inflammatory responses in dairy cattle. Res. Vet. Sci. 2018, 116, 4-14. [CrossRef] [PubMed]

26. Silanikove, N.; Merin, U.; Shapiro, F.; Leitner, G. Subclinical mastitis in goats is associated with upregulation of nitric oxide-derived oxidative stress that causes reduction of milk antioxidative properties and impairment of its quality. J. Dairy Sci. 2014, 97, 3449-3455. [CrossRef] 
27. Blekas, G.; Vassilakis, C.; Harizanis, C.; Tsimidou, M.; Boskou, D.G. Biophenols in table olives. J. Agric. Food Chem. 2002, 50, 3688-3692. [CrossRef]

28. Vilaplana-Perez, C.; Aunon, D.; Garcia-Flores, L.A.; Gil-Izquierdo, A. Hydroxytyrosol and potential uses in cardiovascular diseases, cancer, and AIDS. Front. Nutr. 2014, 1, 18. [CrossRef]

29. Crupi, R.; Palma, E.; Siracusa, R.; Fusco, R.; Gugliandolo, E.; Cordaro, M.; Impellizzeri, D.; De Caro, C.; Calzetta, L.; Cuzzocrea, S.; et al. Protective Effect of Hydroxytyrosol Against Oxidative Stress Induced by the Ochratoxin in Kidney Cells: In vitro and in vivo Study. Front. Vet. Sci. 2020, 7, 136. [CrossRef]

30. Martinez, L.; Ros, G.; Nieto, G. Hydroxytyrosol: Health Benefits and Use as Functional Ingredient in Meat. Medicines 2018, 5, 13. [CrossRef]

31. Parkinson, L.; Cicerale, S. The Health Benefiting Mechanisms of Virgin Olive Oil Phenolic Compounds. Molecules 2016, 21, 1734. [CrossRef]

32. Fuccelli, R.; Fabiani, R.; Rosignoli, P. Hydroxytyrosol Exerts Anti-Inflammatory and Anti-Oxidant Activities in a Mouse Model of Systemic Inflammation. Molecules 2018, 23, 3212. [CrossRef] [PubMed]

33. Larussa, T.; Imeneo, M.; Luzza, F. Olive Tree Biophenols in Inflammatory Bowel Disease: When Bitter is Better. Int. J. Mol. Sci. 2019, 20, 1390. [CrossRef] [PubMed]

34. Amini, A.; Liu, M.; Ahmad, Z. Understanding the link between antimicrobial properties of dietary olive phenolics and bacterial ATP synthase. Int. J. Biol. Macromol. 2017, 101, 153-164. [CrossRef] [PubMed]

35. Furneri, P.M.; Piperno, A.; Sajia, A.; Bisignano, G. Antimycoplasmal activity of hydroxytyrosol. Antimicrob. Agents Chemother. 2004, 48, 4892-4894. [CrossRef] [PubMed]

36. Belaqziz, M.; Tan, S.P.; El-Abbassi, A.; Kiai, H.; Hafidi, A.; O’Donovan, O.; McLoughlin, P. Assessment of the antioxidant and antibacterial activities of different olive processing wastewaters. PLoS ONE 2017, 12, e0182622. [CrossRef] [PubMed]

37. Friedman, M.; Rasooly, R.; Do, P.M.; Henika, P.R. The olive compound 4-hydroxytyrosol inactivates Staphylococcus aureus bacteria and Staphylococcal Enterotoxin A (SEA). J. Food Sci. 2011, 76, M558-M563. [CrossRef]

38. Peterson, D.G.; Matitashvili, E.A.; Bauman, D.E. The inhibitory effect of trans-10, cis-12 CLA on lipid synthesis in bovine mammary epithelial cells involves reduced proteolytic activation of the transcription factor SREBP-1. J. Nutr. 2004, 134, 2523-2527. [CrossRef]

39. Al-Bataineh, M.M.; van der Merwe, D.; Schultz, B.D.; Gehring, R. Tumor necrosis factor alpha increases P-glycoprotein expression in a BME-UV in vitro model of mammary epithelial cells. Biopharm. Drug Dispos. 2010, 31, 506-515. [CrossRef]

40. Zhao, C.; Meng, L.; Hu, H.; Wang, X.; Shi, F.; Wang, Y.; Li, Q.; Lin, A. Spontaneously immortalised bovine mammary epithelial cells exhibit a distinct gene expression pattern from the breast cancer cells. BMC Cell Biol. 2010, 11, 82. [CrossRef]

41. Sobolewska, A.; Motyl, T.; Gajewska, M. Role and regulation of autophagy in the development of acinar structures formed by bovine BME-UV1 mammary epithelial cells. Eur. J. Cell Biol. 2011, 90, 854-864. [CrossRef]

42. Brophy, B.; Smolenski, G.; Wheeler, T.; Wells, D.; L'Huillier, P.; Laible, G. Cloned transgenic cattle produce milk with higher levels of beta-casein and kappa-casein. Nat. Biotechnol. 2003, 21, 157-162. [CrossRef]

43. Lyons, W. Hormonal synergism in mammary growth. Proc. R. Soc. Lond. Ser. B Biol. Sci. 1958, 149, 303-325.

44. Huynh, H.T.; Robitaille, G.; Turner, J.D. Establishment of bovine mammary epithelial cells (MAC-T): An in vitro model for bovine lactation. Exp. Cell Res. 1991, 197, 191-199. [CrossRef]

45. Lee, H.Y.; Heo, Y.T.; Lee, S.E.; Hwang, K.C.; Lee, H.G.; Choi, S.H.; Kim, N.H. Short communication: Retinoic acid plus prolactin to synergistically increase specific casein gene expression in MAC-T cells. J. Dairy Sci. 2013, 96, 3835-3839. [CrossRef] [PubMed]

46. Heo, Y.T.; Ha, W.T.; Lee, R.; Lee, W.Y.; Jeong, H.Y.; Hwang, K.C.; Song, H. Mammary alveolar cell as in vitro evaluation system for casein gene expression involved in glucose level. Asian Australas. J. Anim. Sci. 2017, 30, 878-885. [CrossRef] [PubMed]

47. Kang, S.; Lee, J.S.; Lee, H.C.; Petriello, M.C.; Kim, B.Y.; Do, J.T.; Lim, D.S.; Lee, H.G.; Han, S.G. Phytoncide Extracted from Pinecone Decreases LPS-Induced Inflammatory Responses in Bovine Mammary Epithelial Cells. J. Microbiol. Biotechnol. 2016, 26, 579-587. [CrossRef] 
48. Li, F.; Wang, W.; Cao, Y.; Liang, D.; Zhang, W.; Zhang, Z.; Jiang, H.; Guo, M.; Zhang, N. Inhibitory effects of astragalin on lipopolysaccharide-induced inflammatory response in mouse mammary epithelial cells. J. Surg. Res. 2014, 192, 573-581. [CrossRef]

49. Liu, M.; Song, S.; Li, H.; Jiang, X.; Yin, P.; Wan, C.; Liu, X.; Liu, F.; Xu, J. The protective effect of caffeic acid against inflammation injury of primary bovine mammary epithelial cells induced by lipopolysaccharide. J. Dairy Sci. 2014, 97, 2856-2865. [CrossRef]

50. Kim, T.I.; Kim, T.G.; Lim, D.H.; Kim, S.B.; Park, S.M.; Hur, T.Y.; Ki, K.S.; Kwon, E.G.; Vijayakumar, M.; Kim, Y.J. Preparation of Nanoemulsions of Vitamin A and C by Microfluidization: Efficacy on the Expression Pattern of Milk-Specific Proteins in MAC-T Cells. Molecules 2019, 24, 2566. [CrossRef]

51. Pizzino, G.; Irrera, N.; Bitto, A.; Pallio, G.; Mannino, F.; Arcoraci, V.; Aliquo, F.; Minutoli, L.; De Ponte, C.; D'Andrea, P.; et al. Cadmium-Induced Oxidative Stress Impairs Glycemic Control in Adolescents. Oxid. Med. Cell Longev. 2017, 2017, 6341671. [CrossRef]

52. Angelopoulou, A.; Warda, A.K.; Hill, C.; Ross, R.P. Non-antibiotic microbial solutions for bovine mastitis live biotherapeutics, bacteriophage, and phage lysins. Crit. Rev. Microbiol. 2019, 45, 564-580. [CrossRef] [PubMed]

53. Basirico, L.; Morera, P.; Dipasquale, D.; Bernini, R.; Santi, L.; Romani, A.; Lacetera, N.; Bernabucci, U. (-)-Epigallocatechin-3-gallate and hydroxytyrosol improved antioxidative and anti-inflammatory responses in bovine mammary epithelial cells. Animal 2019, 13, 2847-2856. [CrossRef] [PubMed]

54. Han, J.; Talorete, T.P.; Yamada, P.; Isoda, H. Anti-proliferative and apoptotic effects of oleuropein and hydroxytyrosol on human breast cancer MCF-7 cells. Cytotechnology 2009, 59, 45-53. [CrossRef]

55. Tarafdar, A.; Pula, G. The Role of NADPH Oxidases and Oxidative Stress in Neurodegenerative Disorders. Int. J. Mol. Sci. 2018, 19, 3824. [CrossRef] [PubMed]

56. Hussain, T.; Tan, B.; Yin, Y.; Blachier, F.; Tossou, M.C.; Rahu, N. Oxidative Stress and Inflammation: What Polyphenols Can Do for Us? Oxid. Med. Cell Longev. 2016, 2016, 7432797. [CrossRef] [PubMed]

57. Martinez-Huelamo, M.; Rodriguez-Morato, J.; Boronat, A.; de la Torre, R. Modulation of Nrf2 by Olive Oil and Wine Polyphenols and Neuroprotection. Antioxidants 2017, 6, 73. [CrossRef] [PubMed]

58. Bellezza, I.; Giambanco, I.; Minelli, A.; Donato, R. Nrf2-Keap1 signaling in oxidative and reductive stress. Biochim. Biophys. Acta Mol. Cell Res. 2018, 1865, 721-733. [CrossRef]

59. Alia, M.; Ramos, S.; Mateos, R.; Granado-Serrano, A.B.; Bravo, L.; Goya, L. Quercetin protects human hepatoma HepG2 against oxidative stress induced by tert-butyl hydroperoxide. Toxicol. Appl. Pharm. 2006, 212, 110-118. [CrossRef]

60. Zhang, H.; Zhang, S.; Wang, J.; Sun, B. Wheat bran feruloyl oligosaccharides protect against AAPH-induced oxidative injury via p38MAPK/PI3K-Nrf2/Keap1-MafK pathway. J. Funct. Foods 2017, 29, 53-59. [CrossRef]

61. Fourquet, S.; Guerois, R.; Biard, D.; Toledano, M.B. Activation of NRF2 by nitrosative agents and H2O2 involves KEAP1 disulfide formation. J. Biol. Chem. 2010, 285, 8463-8471. [CrossRef]

62. Clarke, J.L.; Murray, J.B.; Park, B.K.; Copple, I.M. Roles of Nrf2 in drug and chemical toxicity. Curr. Opin. Toxicol. 2016, 1, 104-110. [CrossRef]

63. Bernard, V.; Young, J.; Chanson, P.; Binart, N. New insights in prolactin: Pathological implications. Nat. Rev. Endocrinol. 2015, 11, 265-275. [CrossRef] [PubMed]

64. Feuermann, Y.; Mabjeesh, S.J.; Shamay, A. Mammary Fat Can Adjust Prolactin Effect on Mammary Epithelial Cells via Leptin and Estrogen. Int. J. Endocrinol. 2009, 2009, 427260. [CrossRef] [PubMed]

65. O'Leary, K.A.; Shea, M.P.; Salituro, S.; Blohm, C.E.; Schuler, L.A. Prolactin Alters the Mammary Epithelial Hierarchy, Increasing Progenitors and Facilitating Ovarian Steroid Action. Stem. Cell Rep. 2017, 9, 1167-1179. [CrossRef] [PubMed]

66. Oh, N.S.; Joung, J.Y.; Lee, J.Y.; Kim, Y.; Kim, S.H. Enhancement of Antioxidative and Intestinal Anti-inflammatory Activities of Glycated Milk Casein after Fermentation with Lactobacillus rhamnosus 4B15. J. Agric. Food Chem. 2017, 65, 4744-4754. [CrossRef]

67. Hennighausen, L.; Robinson, G.W.; Wagner, K.U.; Liu, W. Prolactin signaling in mammary gland development. J. Biol. Chem. 1997, 272, 7567-7569. [CrossRef] 
68. Wu, T.; Wang, C.; Ding, L.; Shen, Y.; Cui, H.; Wang, M.; Wang, H. Arginine Relieves the Inflammatory Response and Enhances the Casein Expression in Bovine Mammary Epithelial Cells Induced by Lipopolysaccharide. Mediat. Inflamm. 2016, 2016, 9618795. [CrossRef]

69. Wang, M.; Xu, B.; Wang, H.; Bu, D.; Wang, J.; Loor, J.J. Effects of Arginine concentration on the in vitro expression of Casein and mTOR pathway related genes in mammary epithelial cells from dairy cattle. PLOS ONE 2014, 9, e95985. [CrossRef] 